\title{
Proteomic profiling of proteins associated with the rejuvenation of Sequoia sempervirens (D. Don) Endl
}

\author{
Ing-Feng Chang ${ }^{1 \dagger}$, Peng-Jen Chen ${ }^{1 \dagger}$, Chin-Hui Shen ${ }^{1 \dagger}$, Tsung-Ju Hsieh${ }^{1}$, Ya-Wen Hsu', Bau-Lian Huang ${ }^{2}$,
} Ching-l Kuo ${ }^{2}$, Yu-Ting Chen ${ }^{3}$, Hsiu-An Chu², Kai-Wun Yeh ${ }^{1 *}$, Li-Chun Huang ${ }^{2 *}$

\begin{abstract}
Background: Restoration of rooting competence is important for rejuvenation in Sequoia sempervirens (D. Don) Endl and is achieved by repeatedly grafting Sequoia shoots after 16 and 30 years of cultivation in vitro.

Results: Mass spectrometry-based proteomic analysis revealed three proteins that differentially accumulated in different rejuvenation stages, including oxygen-evolving enhancer protein 2 (OEE2), glycine-rich RNA-binding protein (RNP), and a thaumatin-like protein. OEE2 was found to be phosphorylated and a phosphopeptide (YEDNFDGNSNVSVMVPTPpTDK) was identified. Specifically, the protein levels of OEE2 increased as a result of grafting and displayed a higher abundance in plants during the juvenile and rejuvenated stages. Additionally, SSOEE2 displayed the highest expression levels in Sequoia shoots during the juvenile stage and less expression during the adult stage. The expression levels also steadily increased during grafting.

Conclusion: Our results indicate a positive correlation between the gene and protein expression patterns of SSOEE2 and the rejuvenation process, suggesting that this gene is involved in the rejuvenation of Sequoia sempervirens.
\end{abstract}

\section{Background}

Plant maturation involves sequential developmental stages or phases that can be categorized as embryo, juvenile, transitional, and adult. The development of reproductively mature adult plants usually begins with a strictly vegetative juvenile phase. Maturation or a phase change is completed within weeks among annuals but can proceed for several years among perennials. In trees, the process is frequently accompanied by ancillary morphological and physiological traits, most commonly a loss of competence for adventitious rooting and a loss of overall vigor. Because a plant's developmental phase is determined in its shoot apical meristems, reversing the phase of the meristems should result in the emergence of rejuvenated shoots [1]. Indeed, new growths with reversed phases have been obtained by applying gibberellin [2] and cytokinin [3,4], continuously

\footnotetext{
* Correspondence: ykwbppp@ntu.edu.tw; bolch@gate.sinica.edu.tw † Contributed equally

${ }^{1}$ Institute of Plant Biology, National Taiwan University, Taipei 106, Taiwan ${ }^{2}$ Institute of Plant and Microbial Biology, Academia Sinica, Taipei, Taiwan Full list of author information is available at the end of the article
}

subculturing shoots, especially in cytokinin-containing media [5-7], and repeatedly grafting shoot apices from mature trees onto juvenile rootstocks in vivo $[8,9]$ and in vitro [10-15].

Sequoia sempervirens (D. Don) Endl, a coastal redwood, can be rejuvenated through repeatedly grafting its adult-phase shoot tips onto juvenile rootstocks in vitro [16], which can result without phytohormonal supplements. Adventitious rooting is notably depressed and essentially absent in tissues of adult trees. The stability of the rejuvenated state by restoring rooting competence and other juvenile characteristics can be retained in vitro even after 30 years. The reversion has been associated with distinctive leaf proteins, including clearly apparent changes in iso-esterase and iso-peroxidase [17], different tyrosine phosphorylation patterns, and higher total protein phosphorylation in juvenile shoots [18]. Juvenile and rejuvenated shoots also released more ethylene [19], had higher total nitrogen content, and were more active in photosynthesis and respiration [20]. This diversity of differences in physiology between juvenile
C Biomed Central

(c) 2010 Chang et al; licensee BioMed Central Ltd. This is an Open Access article distributed under the terms of the Creative Commons Attribution License (http://creativecommons.org/licenses/by/2.0), which permits unrestricted use, distribution, and reproduction in any medium, provided the original work is properly cited. 
and adult Sequoia shoots reflect the complexity of the developmental phase change.

In 1991 , a $16 \mathrm{kDa}$ protein was found to be only produced in juvenile or rejuvenated meristems [21]. In 1996 , a $28 \mathrm{kDa}$ protein was found to be expressed in greater amounts in juvenile shoot tips than mature shoot tips [22]. Moreover, Gil et al. (2003) identified a cDNA clone termed Quercus robur crown preferentially expressed (QRCPE) that was differentially expressed in juvenile-like and mature shoots in Quercus robur. QRCPE appeared to be a cell-wall protein [23]. However, the proteomic differences in adult, juvenile, and rejuvenated tree species are not well known. Using a proteomics approach, candidate regulatory components of the rejuvenation of tree species may be identified. In the present study, Sequoia was utilized as our rejuvenation system, and gel-based proteomic analysis was performed. Three proteins with differential abundance in adult, juvenile, and rejuvenated Sequoia were identified by mass spectrometry (MS), including oxygen-evolving enhancer protein 2 (OEE2), glycine-rich RNA-binding protein (RNP) and a thaumatin-like protein (TLP). Results from the gene expression and protein accumulation pattern indicated a positive correlation between OEE2 and the rejuvenation stages, suggesting that OEE2 may be involved in the rejuvenation of Sequoia.

\section{Results}

The restored rooting competence of repeatedly grafted Sequoia shoots is retained after $\mathbf{3 0}$ years of culture in vitro

Sequoia shoot cultures initiated in 1976 and 1994 had retained their hallmark characteristics. Those in the adult phase were rootless, had enervated shoots, and grew very slowly compared with juvenile phase cultures (Figure 1). These developmental stage-specific samples included adult cultured shoots established in 1976 (Adult76) and 1994 (Adult94) and juvenile and rejuvenated (Rejuvenated) shoots. However, rooting was substantially restored among adult shoots that had been grafted four times onto juvenile rootstocks in 1976 and after three times in 1994.

\section{Two-dimensional gel electrophoresis of proteins}

Mass spectrometry (MS)-based proteomic analysis has been widely used to identify differentially expressed proteins at different stages of plant development [24]. Huang et al. (1992) used two-dimensional gel electrophoresis and discovered pattern differences among proteins extracted from adult, juvenile, and rejuvenated shoot cultures, in which the rejuvenated cultures were obtained by repeatedly grafting adult onto juvenile stock [16]. However, the proteins were not identified. Thus, the present study identified some of the differentially expressed proteins.

Total proteins were isolated from A cultured shoots established in 1976 (Adult76) and 1994 (Adult94) and juvenile and rejuvenated cultured shoots (Rejuvenated76 and Rejuvenated94). The protein extracts were subjected to two-dimensional gel electrophoresis with at least three biological replicates analyzed for each type of tissue. The protein gel images are shown in Figure 2. At least three distinctive protein spots with differential intensity were detected. The relative intensity of each protein spot was quantified using SameSpots software (Progenesis, USA).

Identification of Sequoia proteins exhibiting up- or downregulated protein abundance during rejuvenation

Three protein spots that showed differential accumulation (labeled 1,2, and 3) in each gel were excised and subjected to in-gel digestion followed by MS (Figure 2). Proteins were identified by a database search using inhouse Mascot software (Table 1). Protein identification was validated using Scaffold software to provide confidence interval percentages (Additional file 1). Oxygenevolving enhancer protein2 (OEE2), glycine-rich RNA binding protein (RNP) and thaumatin-like protein (TLP) were consistently identified in the three biological replicates. Specifically, two identified proteins, RNP and OEE2, showed increased protein abundance during the rejuvenation stage (Figure 3), whereas TLP showed decreased protein abundance during the rejuvenation stage (Figure 3). In addition to spots 1, 2, and 3, three other proteins from other spots were also identified. The proteins included glyoxysomal malate dehydrogenase, class I chitinase and a LRR-repeat protein (Additional file 2). However, these proteins were not consistently identified in all five protein gel samples.

Our detailed studies were confined to OEE2, RNP and TLP. The deduced amino acid sequences of OEE2, RNP and TLP were shown in Figure 4A,F, Figure 5 and Figure 6A, respectively. These sequences were entered into the database, and an additional database search was performed with in-house Mascot software. More peptides were identified, and the sequence coverage was greatly increased (Table 1 Figure 4 Figure 5 Figure 6). OEE2 was identified in spot 1, with a predicted molecular mass of $27.7 \mathrm{kD}$. However, the apparent molecular mass of OEE2 on the protein gel was approximately $21 \mathrm{kD}$, which was much smaller than expected. Additionally, the $\mathrm{N}$-terminus peptide fragments of OEE2 were not discovered in this study (Table 1). Altogether, the results suggest that the identified OEE2 is a chloroplast form without the transit peptide. The transit peptide of OEE2 could be cleaved by a protease before translocation into the chloroplast. 

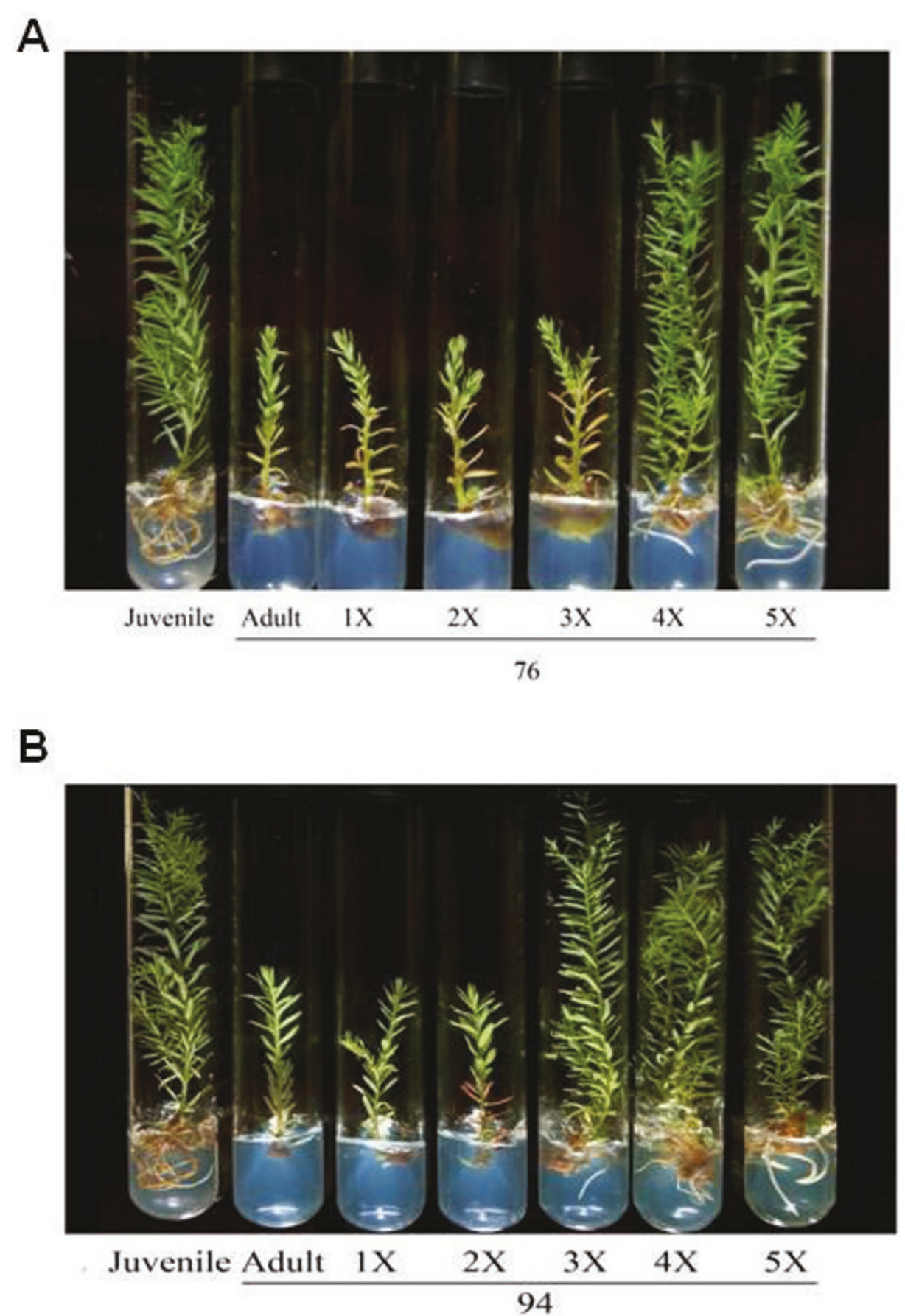

Figure 1 The restoration of rooting competence in Sequoia shoots established in (A) 1976 and (B) 1994. Left to right: juvenile, adult, and adults with one, two, three, four, or five grafts. 


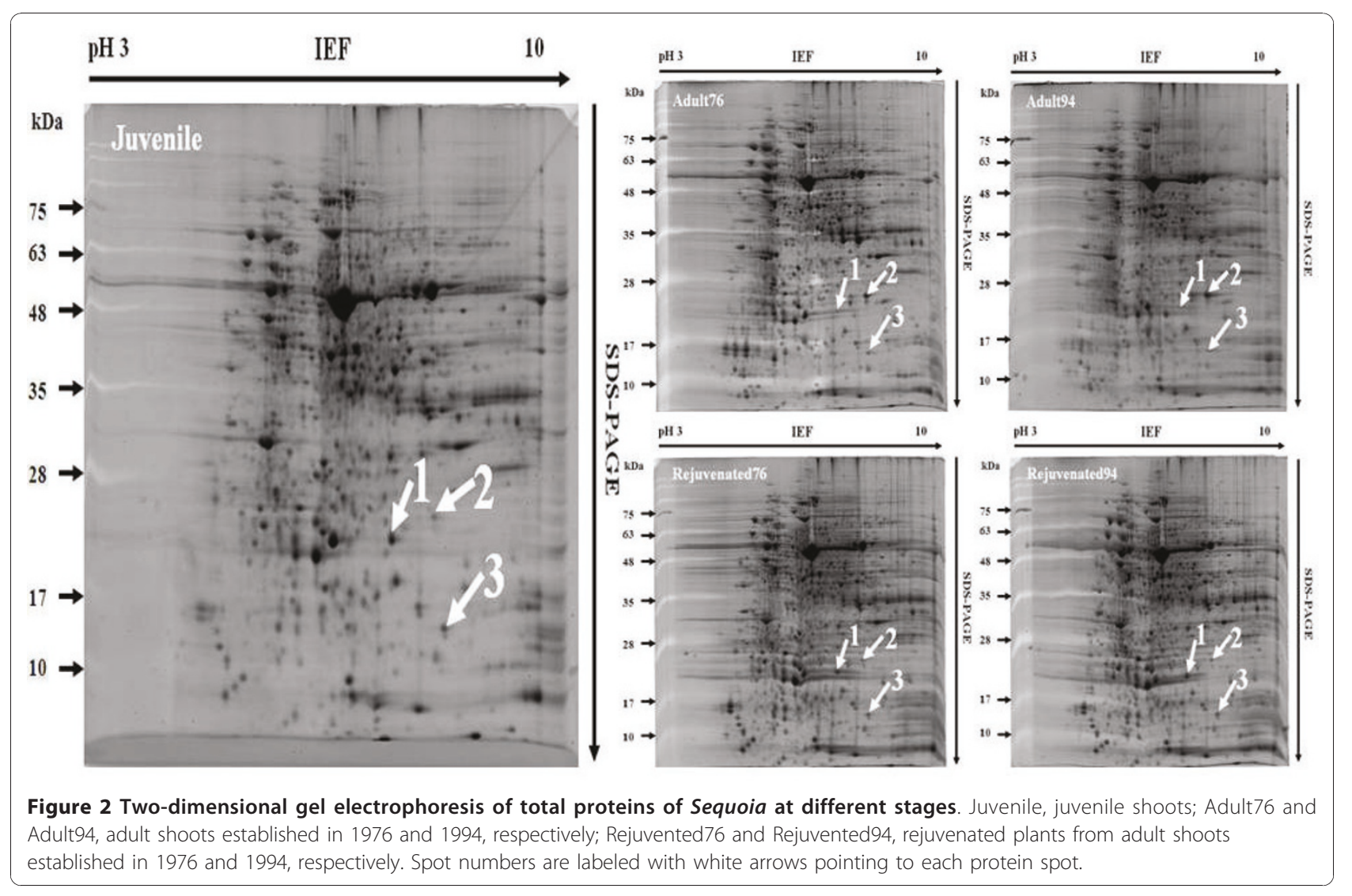

Without including the Sequoia OEE2 protein sequence in the database, only two OEE2 peptides were identified (Table 1). A Mascot protein score of 2017 was obtained when including Sequoia OEE2 in the database. Thirteen OEE2 peptides, including a phosphopeptide, were identified. The protein coverage was $52 \%$. The phosphopeptide of OEE2 was doubly phosphorylated (YEDNFDGNSNVSVMVpTPpTDK), and the MS/ MS spectrum of the phosphopeptide is shown in Figure 7. This phosphopeptide was validated by Scaffold, with a confidence interval $>95 \%$ (Additional file 1).

RNP was identified in spot 3 . Without including the RNP protein sequence in the database, only one peptide was identified (Table 1). The Mascot protein score was 67 , and the protein coverage was $11 \%$. The Mascot protein score was 1155 when including the Sequoia RNP protein sequence in the database. Fourteen peptides were identified, and the protein coverage was $61 \%$. TLP was identified in spot 2. The Mascot protein score was 833, and three peptides were identified.

\section{Protein levels of OEE2, RNP, and TLP in repeatedly grafted Sequoia shoots}

All of the above three proteins were consistently identified in the three biological replicates. OEE2 protein abundance was found to be up-regulated in Rejuvenated76 and Rejuvenated94. The protein level in the adult specimen (Adult76 and Adult94) was lower than the juvenile and rejuvenated samples (Figure 3). Adult76 and Adult94 were significantly different from Juvenile, Rejuvenated 76 and Rejuvenated94 ( $p<0.05$; one-way analysis of variance [ANOVA] followed by Duncan's multiple range test for statistical analysis of means) (Additional file $3 \& 4$ ). The protein abundance of OEE2 through the steps of repeated grafting showed a positive correlation between rejuvenation and protein abundance in Sequoia shoot cultures initiated in both 1976 and 1994 (Figure 3).

By contrast, the protein abundance of RNP was found to be up-regulated in Rejuvenated94 but not Rejuvenated76. The protein level of RNP in the adult plantlet (Adult76 and Adult94) was lower than the Juvenile and Rejuvenated94 samples (Figure 3). However, Adult76 and Adult94 were not significantly different from Juvenile, Rejuvenated76 and Rejuvenated 94 ( $p<0.05$; oneway ANOVA followed by Duncan's multiple range test for statistical analysis of means) (Additional file 3, 4). Therefore, the protein abundance of RNP through the steps of repeated grafting showed no correlation between rejuvenation and protein abundance in Sequoia shoot cultures initiated in 1976 or 1994 (Figure 3). 
Table 1 Identification of proteins differentially accumulated in different rejuvenation cultures of Sequoia sempervirens

\begin{tabular}{|c|c|c|c|c|c|c|c|c|}
\hline $\begin{array}{l}\text { Spot } \\
\text { Number }\end{array}$ & Protein Name & $\mathrm{PS}^{\mathrm{a}}$ & $\mathrm{pl}$ & Mass & $\begin{array}{l}\text { Entry } \\
\text { mass }\end{array}$ & $\begin{array}{l}\text { Theoretical } \\
\text { mass }\end{array}$ & $\begin{array}{l}\text { Peptide } \\
\text { Score }\end{array}$ & Peptide Sequence \\
\hline \multirow[t]{14}{*}{1} & $\begin{array}{l}\text { Oxygen-evolving enhancer } \\
\text { protein } 2\end{array}$ & 2017 & 6.02 & 27705 & 848.1996 & 848.3512 & 16 & TADGDEGGK \\
\hline & $(N=3)$ & & & & 1188.3712 & 1188.6139 & 49 & EVEYPGQVLR \\
\hline & & & & & 1227.3166 & 1227.5772 & 54 & FVESAASSFNVA \\
\hline & & & & & 1243.3977 & 1242.6608 & 32 & QYYTLSVLTR \\
\hline & & & & & 1254.4093 & 1254.6568 & 71 & HQLISATVSDGK \\
\hline & & & & & 1294.3918 & 1294.6193 & 89 & AYGEAANVFGAPK \\
\hline & & & & & 1356.4217 & 1355.6721 & 27 & KFVESAASSFNVA \\
\hline & & & & & 1477.4212 & 1477.6725 & 84 & NTDFITYSGEGFK \\
\hline & & & & & 1605.4551 & 1605.7675 & 56 & KNTDFITYSGEGFK \\
\hline & & & & & 2084.6029 & 2084.9975 & 90 & TADGDEGGKHQLISATVSDGK \\
\hline & & & & & 2246.5382 & 2246.9638 & 75 & YEDNFDGNSNVSVMVTPTDK ${ }^{b}$ \\
\hline & & & & & 2390.6106 & 2390.9015 & 56 & YEDNFDGNSNVSVMVPTPpTDK \\
\hline & & & & & 2374.6248 & 2375.0587 & 77 & YEDNFDGNSNVSVMVTPTDKK ${ }^{b}$ \\
\hline & & & & & 2688.8683 & 2689.3195 & 110 & TASEGGFDTNAVATAALLESGNPWNGK \\
\hline \multirow[t]{4}{*}{2} & Thaumatin-like protein & 833 & 8.97 & 24687 & 1056.2335 & 1056.4295 & 83 & TGCSFDASGR $^{d}$ \\
\hline & $(N=3)$ & & & & 1271.4018 & 1271.5605 & 62 & GQCPQAYSYAK ${ }^{d}$ \\
\hline & & & & & 1764.3805 & 1763.7309 & 31 & DDATSTFTCPSGTNYK ${ }^{d}$ \\
\hline & & & & & 1863.5394 & 1863.9070 & 89 & ITCLSDINSKCPSELK ${ }^{d}$ \\
\hline \multirow[t]{9}{*}{3} & $\begin{array}{l}\text { Glycine-rich RNA-binding } \\
\text { protein } 2\end{array}$ & 1155 & 5.18 & 18530 & 963.2489 & 963.4661 & 76 & ASAEIEFR + N-acetyl \\
\hline & $(N=3)$ & & & & 1031.3243 & 1031.5360 & 37 & IVSDRETGR \\
\hline & & & & & 1129.4603 & 1129.5840 & 54 & NITVNQAQSR \\
\hline & & & & & 1165.3100 & 1165.5225 & 43 & SGGGGYGGGGRER \\
\hline & & & & & 1486.3225 & 1486.6186 & 114 & YGGGSGGYGGGAGGGGGSR \\
\hline & & & & & 1699.6421 & 1699.8601 & 46 & ELDGRNITVNQAQSR \\
\hline & & & & & 1761.5227 & 1761.8574 & 72 & SLHDAFSPFGEVLESK \\
\hline & & & & & 2542.5518 & 2543.0655 & 18 & GFGFVTFSDEQAMMDAIEAMNGK ${ }^{b}$ \\
\hline & & & & & 3112.7218 & 3113.3416 & 59 & GFGFVTFSDEQAMMDAIEAMNGKELDGR \\
\hline
\end{tabular}

a: Mascot protein score; b: M: oxidized methionine; c: p: Threonine phosphorylation; d: C: carbamidomethyl modified cysteine.

TLP abundance was found to be down-regulated in Rejuvenated76 and Rejuvenated94. The protein level in the adult specimen (Adult76 and Adult94) was higher than the Juvenile and Rejuvenated samples (Figure 3). Adult76 and Adult94 were significantly different from Juvenile, Rejuvenated76 and Rejuvenated $94(p<0.05$; one-way ANOVA followed by Duncan's multiple range test for statistical analysis of means) (Additional file 3, 4). The protein abundance of TLP through the steps of repeated grafting showed a reverse correlation between rejuvenation and protein abundance in Sequoia shoot cultures initiated in both 1976 and 1994 (Figure 3).

\section{Phylogenetic analysis of OEE2, TLP and RNP}

The full-length cDNAs of the SsOEE2, SsTLP, and SsRNP genes were cloned from Sequoia shoots in vitro and further analyzed. The cDNA length of SsOEE2 was $981 \mathrm{bps}$ and encoded a predicted $27.7 \mathrm{kDa}$ protein. The isoelectric point of SsOEE2 was 9.18. SsOEE2 contained a signal peptide for chloroplast in the $\mathrm{N}$-terminal. Phylogenetic analysis of OEE2 by the neighbor-joining method revealed that the Sequoia sempervirens protein had $49-71 \%$ homology in the amino acid sequence with the protein of other species (Figure 4B). The peptide sequence of OEE2, among gymnosperms, was conserved and displayed diversity from those of algae and other angiosperms. The cDNA length of SsTLP was 896 bps and encoded a predicted $24.7 \mathrm{kDa}$ protein. The isoelectric point of TLP was 8.62. It contained a secretory signal peptide in the $N$-terminal. The phylogenetic analysis of TLP, based on calculations by the neighbor-joining method, revealed that Sequoia sempervirens had 43-71\% homology in the amino acid sequence with the other species (Figure 5B). The peptide sequence of TLP was conserved among gymnosperms and angiosperms.

The cDNA length of SsRNP was 1123 bps and encoded a predicted $18.5 \mathrm{kDa}$ protein. The isoelectric point of RNP was 8.05 and contained a nuclear 

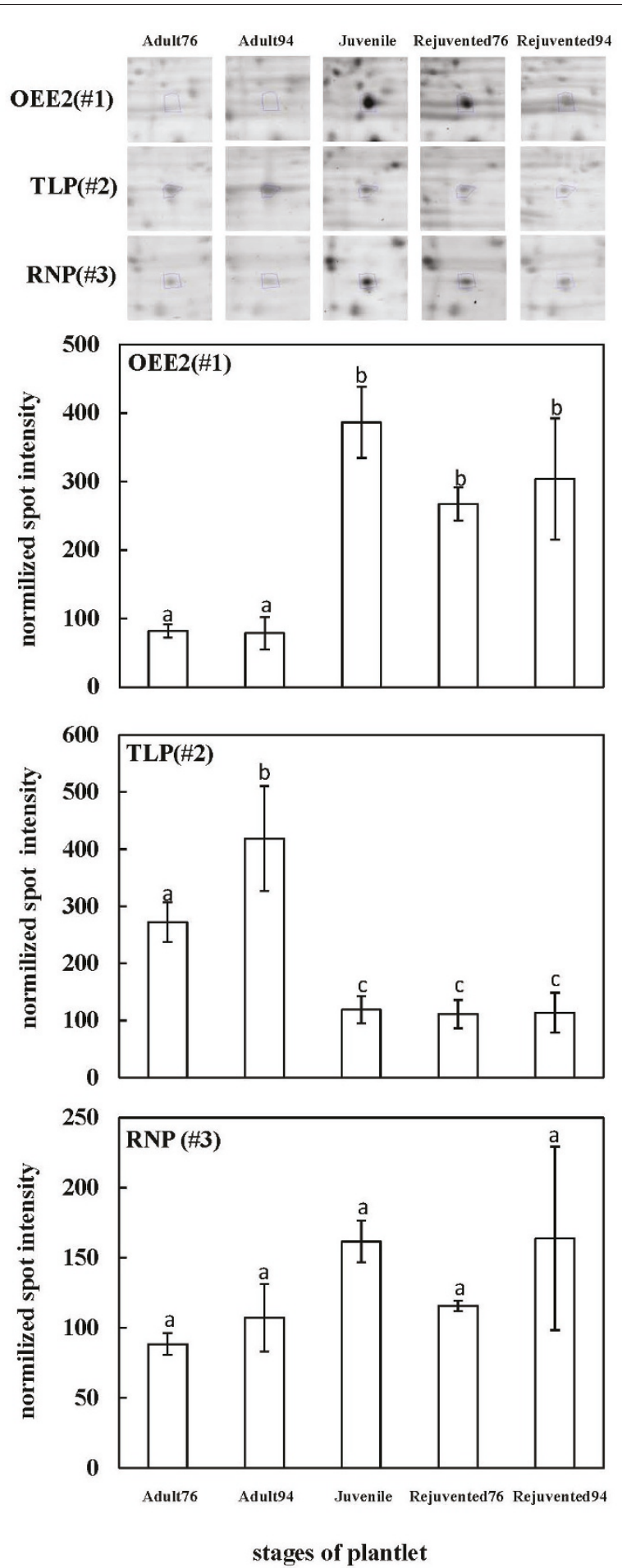

Figure 3 Diagram and quantification of OEE2, TLP, and RNP in different stages. (A) Juvenile, juvenile shoots; Aduult76 and Adult94, adult shoots established in 1976 and 1994, respectively; Rejuvenated76 and Rejuvenated94, rejuvenated plants from adult shoots established in 1976 and 1994, respectively. Identified spots are demarcated by the blue line in each gel. (B) Means of the samples were analyzed by ANOVA. Bars having different letters are significantly different ( $p<0.05$, ANOVA followed by Duncan's multiple range test). 


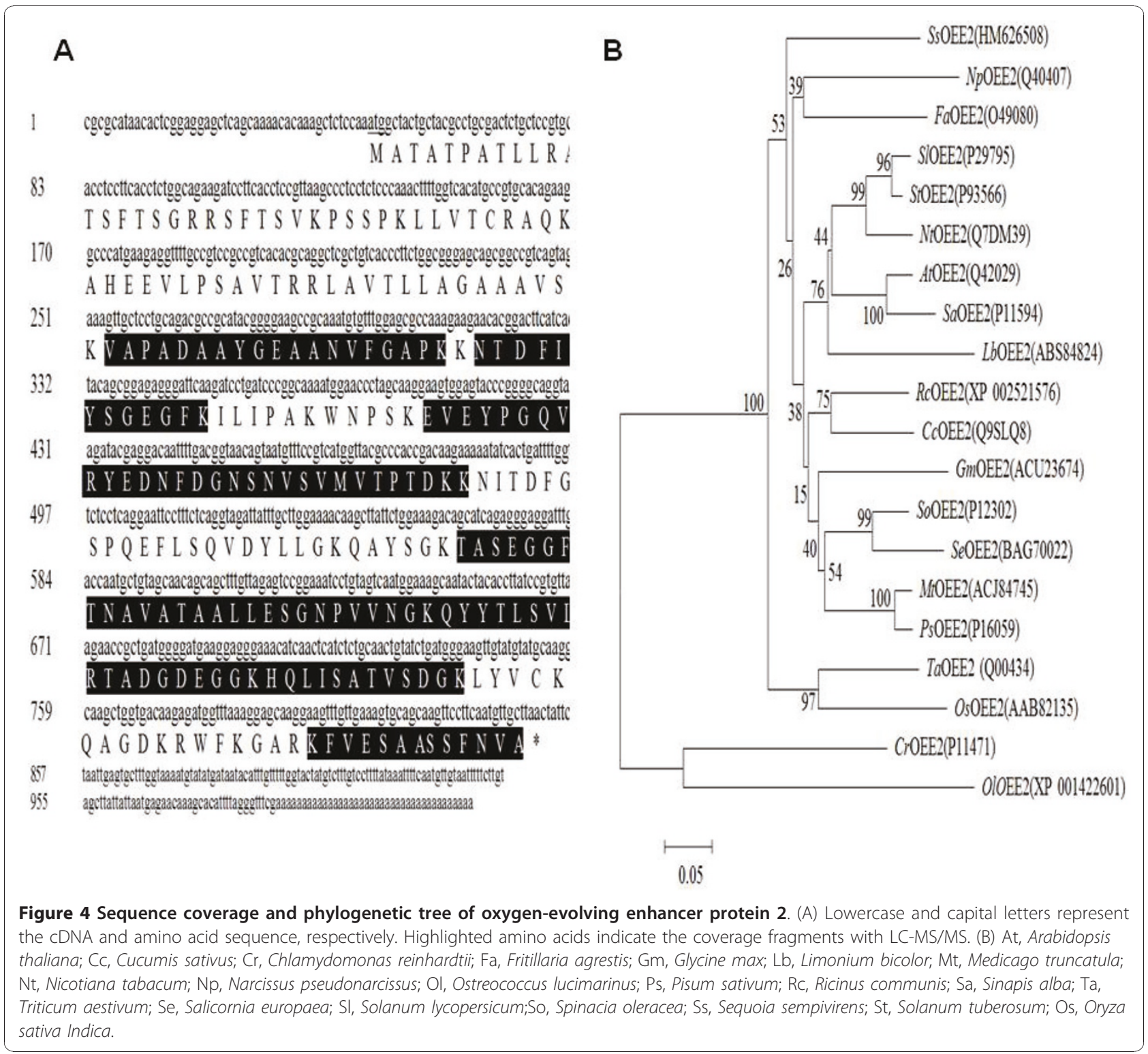

localization signal in the $C$-terminal. The phylogenetic analysis of RNP, based on calculations by the neighborjoining method, revealed that Sequoia sempervirens shared $49-79 \%$ homology in the amino acid sequence with the other species (Figure 6B). The peptide sequence of RNP, among gymnosperms, was conserved and displayed diversity from those of angiosperms.

\section{Gene expression patterns of up- or down-regulated genes} in repeatedly grafted Sequoia shoots

To further explore the role of up- or down-regulated genes in phase changes, the expression patterns of SsOEE2, SsRNP, and SsTLP in the two adult shoot cultures, established in 1976 and 1994, respectively, were monitored following repeated grafting (Figure 8). Both
SsOEE2 and SsRNP displayed higher expression levels in the juvenile phase and a lower expression level in the adult phase (Figure 8). Furthermore, their expression levels also steadily increased with the number of repeated grafts. Specifically, a higher expression level of SsOEE2 was present in the Sequoia shoots during the juvenile and rejuvenated stages, which is consistent with the protein accumulation pattern (Figure 3 ). However, the expression level of SsRNP displayed a similar pattern at different stages in Sequoia shoots initiated in 1976 but increased slightly with repeated grafting initiated in 1994.

By contrast, the expression level of SsTLP in adult shoots was initially high but progressively decreased with repeated grafting. The expression pattern of SsTLP was opposite to SSOEE2 and decreased with repeated 


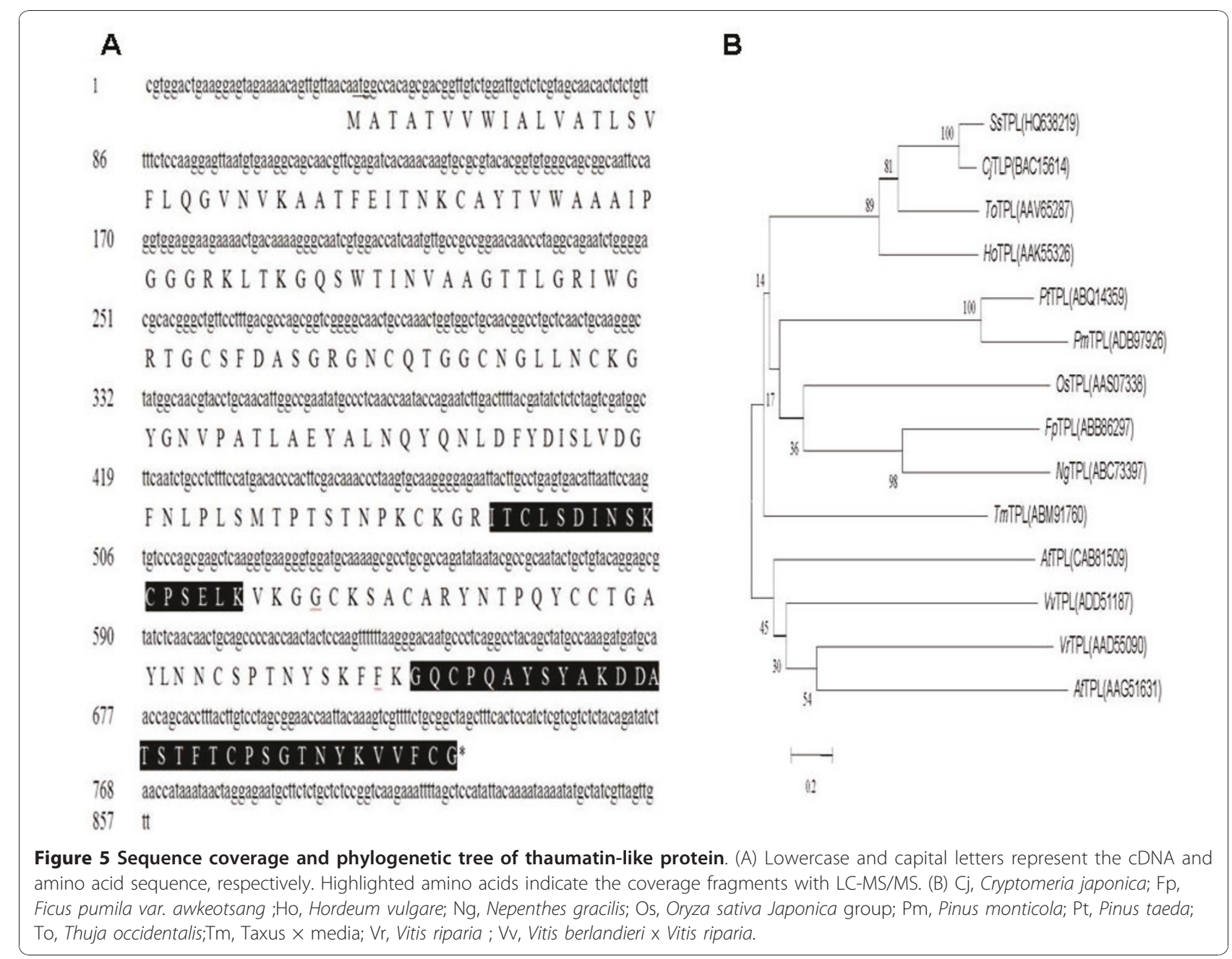

grafting (Figure 8). The highest expression level of SsTLP was present in Sequoia shoots during the adult stage and significantly decreased with one-time Sequoia grafting initiated in 1976 and the third Sequoia grafting initiated in 1994.

\section{Discussion}

Plant maturation involves a sequence of developmental stages or phases that can be categorized as embryo, juvenile, transitional and adult. Aging in perennials is very complex, and no consensus has been achieved in the general concepts related to this topic [25]. A juvenile phase occurs in all woody plants, which lasts up to 30-40 years in certain forest trees, during which flowering does not occur. The physiology and molecular biology aspects are then considered when listing biochemical markers of maturation in woody plants. These markers occur as part of primary and secondary metabolism (e.g., mineral and carbon nutrition, growth regulators, polyamines, phenolic compounds, and peroxidase activity) and gene expression (e.g., nucleic acids, transcription and proteic synthesis) [25-28].

The transition leading to adulthood is accompanied by changes in morphological characteristics, such as a loss of adventitious rooting, modification of leaf morphology, an enervated growth rate, and a variation in phytohormone levels [29-31]. The process of rejuvenation of the adult shoot apex or inflorescence reversion was identical in planta and well characterized by research that showed some of the key genes involved in the reversion of determinate floral meristem to indeterminate shoot meristem $[32,33]$. However, most species are less prone to maturational stage reversion because signals from the leaf are less ephemeral even when its initiation is dependent on environmental cues. Several plants undergo rejuvenation when exposed to optimal stimuli, such as gibberellins [34], cytokinin [35], ABA [36], and grafting [16]. Grafting is known to cause phase reversion in woody perennials (e.g., citrus [37], cupressus [38], eucalyptus [38], hedera [39], passiflora [40], pseudotsuga [41], and avocado [14]. 


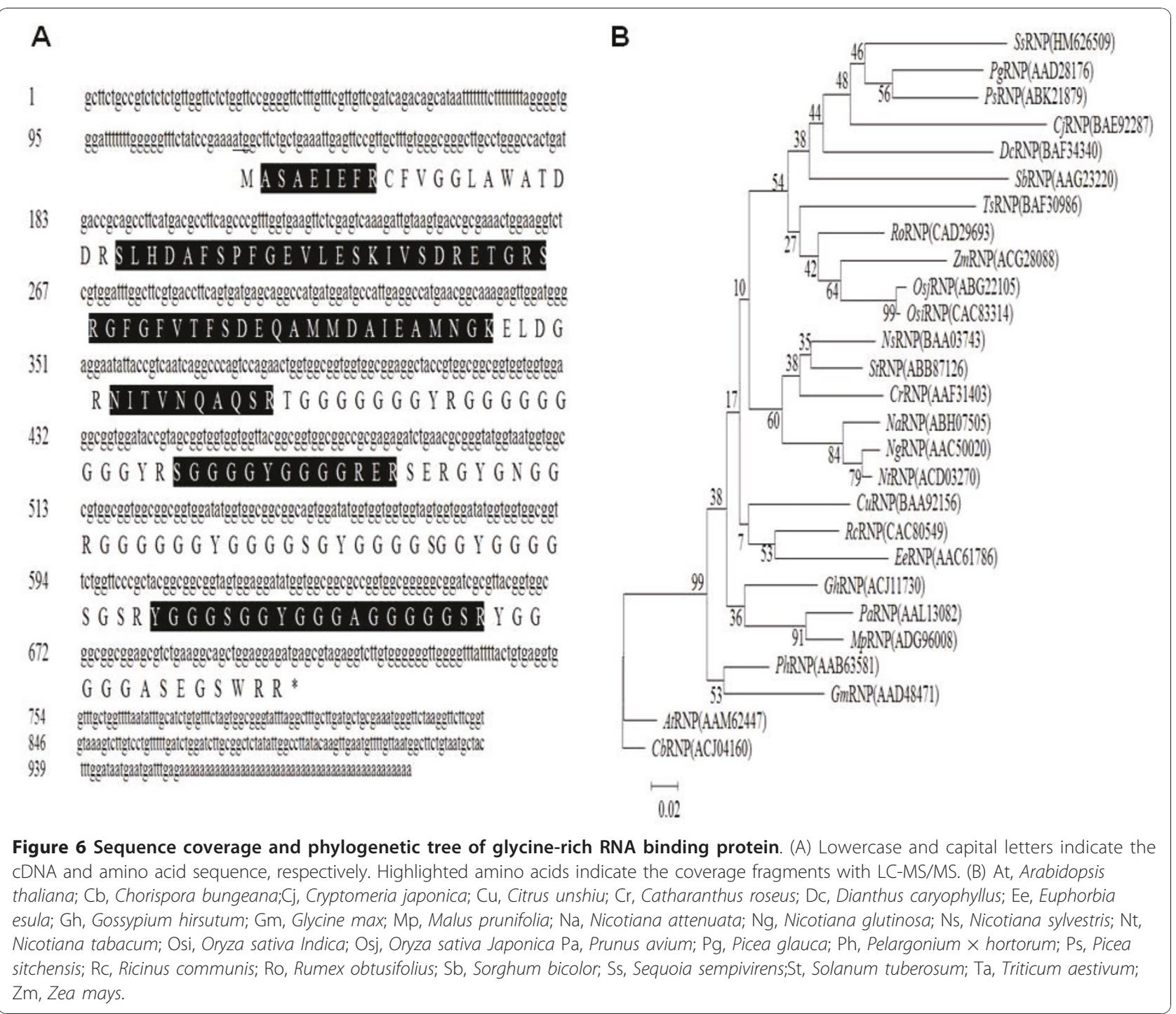

The factors triggering maturation and phase transition and how this process is regulated in terms of changes in gene expression, cellular signaling, and metabolism are well known. Unfortunately, most of the established knowledge on phase transition is based on annual Arabidopsis or rice. Much less genetic evidence has been obtained regarding rejuvenation in perennials. We focused on Sequoia proteins and genes that displayed an identical pattern at different developmental stages, and advances in proteomics has helped unravel some of the particular features of rejuvenation in Sequoia.

\section{Identification of OEE2 protein}

OEE2 is a core component of the PSII complex in the chloroplast in plants [42]. Evidence has shown that OEE2 in higher plants can only associate with the PSII core complex through OEE1 and OEE3. The oxygen- evolving capacity of PSII decreased to as low as $5-10 \%$ in the absence of OEE2 [42]. Based on the literature, the accumulation of OEE2 can be regulated by plant hormones. The abundance of OEE2 increased in the cytokinin-treated moss Physcomitrella patens [43]. The accumulation of OEE 2 can also be regulated by abiotic stress. Up-regulated OEE protein levels have also been detected in E. elongatum and Norway spruce during drought stress $[44,45]$ and in rice undergoing salt stress and metal treatment [46]. Furthermore, the accumulation of OEE2 can be regulated by development. The photosynthetic rate and expression level of $O E E$ increased in leaves of maize which roots were colonized by Trichoderma virens [47].

A decrease in photosynthesis with increased aging has been shown to be a significant feature of several trees [27]. Higher rates of photosynthesis and chlorophyll $a / b$ 


\section{YEDNFDGNSNVSVMVpTPpTDK}

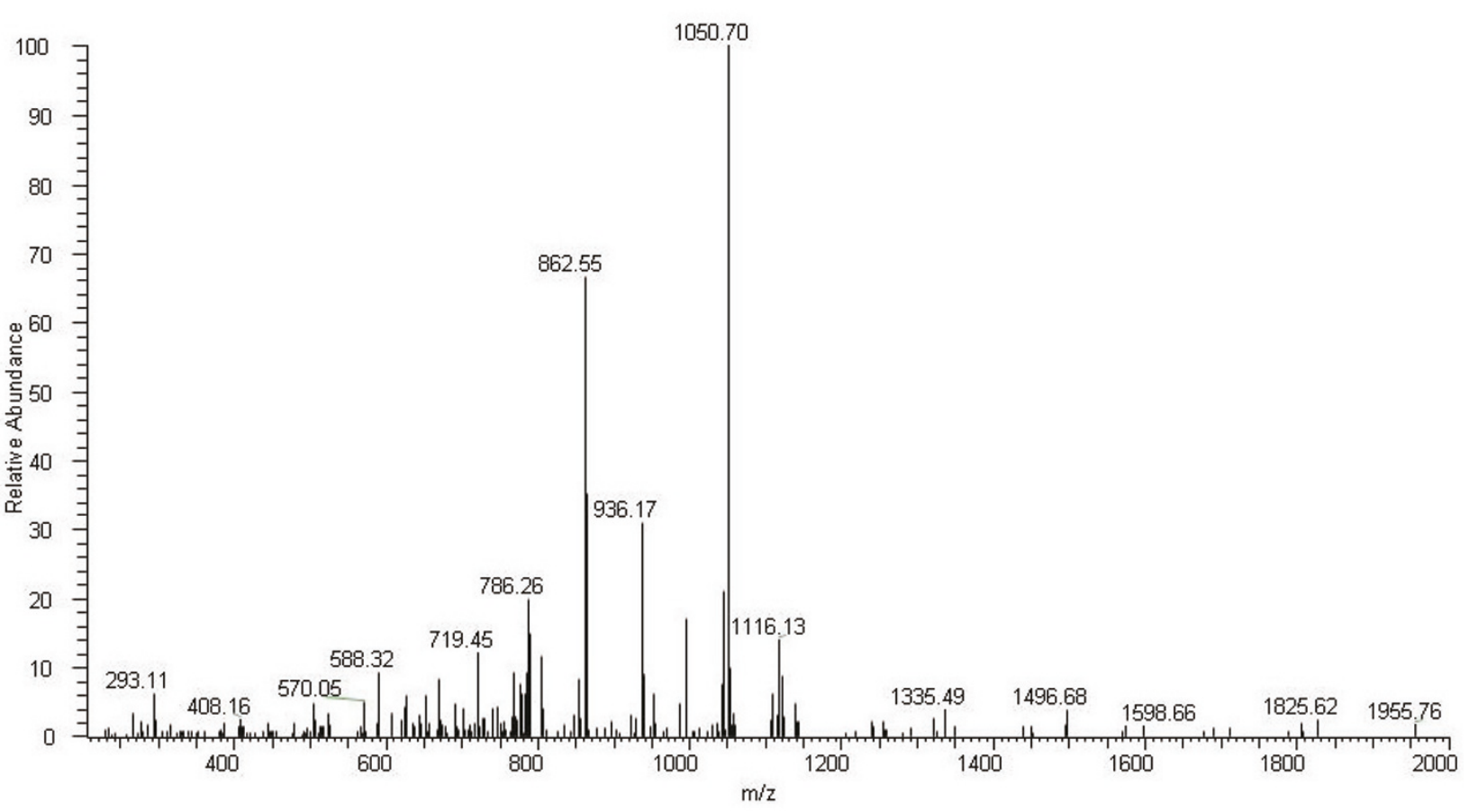

Figure $7 \mathrm{MS} / \mathrm{MS}$ fragmentation pattern of the phosphopeptide of SsOEE2. The phosphopeptide (YEDNFDGNSNVSVMVpTPpTDK) included two phosphorylation sites, labeled with $p$ next to the site.

ratios were present during the juvenile and rejuvenate stages, but quantum efficiencies of PSII indicated equivalent effectiveness in the juvenile, rejuvenate, and adult stages. Recent studies have demonstrated RNA interference (RNAi) in PsbP protein, which has greater homology with $S s O E E 2$, with similar results in tobacco [48]. Therefore, the increasing expression level of SsOEE2 is a critical event for restoring the net photosynthesis rate. Furthermore, the photosynthesis rate and expression level of $O E E$ were increased in maize leaves when the roots were colonized by Trichoderma virens [47]. Moreover, the plant in the adult stage is much shorter in the juvenile stage (Figure 1). With PsbP protein knockout in tobacco, the transgenic plant phenotype displayed dramatic growth retardation and also decreases in the chlorophyll $a / b$ ratio and oxygen evolution [49]. This indicated the effect of roots on sink activity and in directing carbon partitioning toward the roots and promoting their development. Therefore, this indicated that active OEE2 is related to nutrient recomposition associated with restoration of rooting and foliar morphology, which were other significant features of Sequoia rejuvenation.

The protein accumulation and gene expression level of SsOEE2 increased through successive grafts in the present study (Figure 3 Figure 8). A positive correlation was found between rejuvenation and protein and transcript abundance of the SsOEE2 gene. This suggested that SsOEE2 may be involved in Sequoia rejuvenation. Specifically, based on the molecular mass, the OEE2 identified in this study appeared to be localized in the chloroplast. Altogether, these results suggest that the chloroplast protein may be involved in Sequoia rejuvenation. Because only plants possess chloroplast, and the fact that rejuvenation found only in plants implicates chloroplast may be one of the regulatory components in plant rejuvenation. In addition, expression of a chlorophyll a/b binding gene was also found to be greater in developing juvenile than in mature foliage [50,51]. It is possible that chloroplast proteins are a key of rejuvenation process in plants. Whether photosynthesis efficiency is altered in Sequoia rejuvenation requires further studies.

\section{Identification of RNP protein}

Plant RNP is a class of genes with diverse functions, and the functions of many of these genes are still unknown. The expression of RNP genes is regulated by abiotic stress (e.g., cold, wounds, and hormones such as auxin and abscisic acid [52]. In Arabidopsis, AtGRP7 has been 


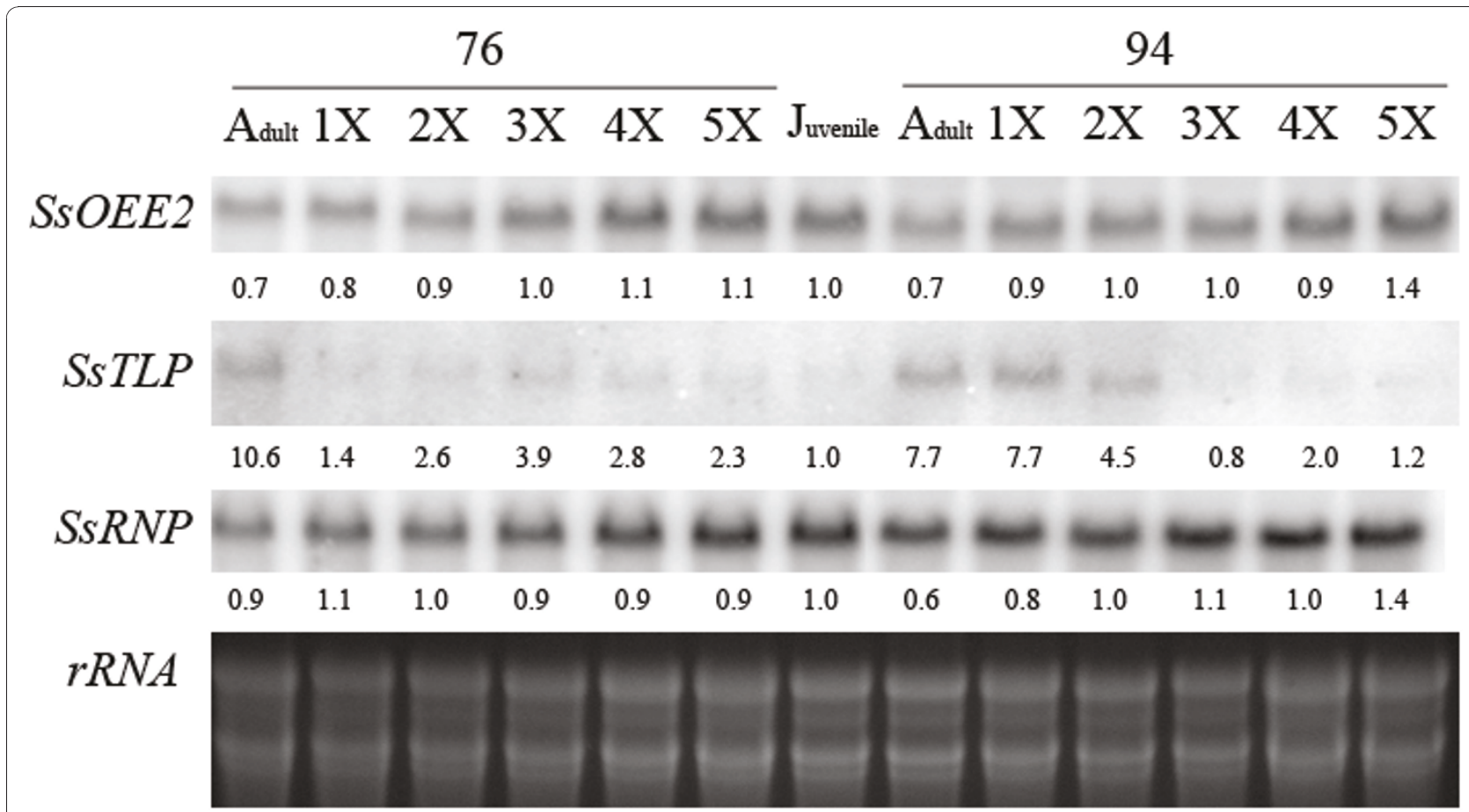

Figure 8 The expression level of SSOEE2, SsRNP and SsTLP in Sequoia shoot during repeated grafting. 76 and 94 are the Sequoia shooting established in 1976 and 1994 respectively. Adult: adult shoot, Juvenile: juvenile shoot 1X 5X: repeated grafting. The expression intensity of SSOEE2, SSRNP and SSTLP were normalized with total rRNA acting as loading control and scoring by comparing to juvenile stage.

widely studied. AtGRP7 has been reported to promote phase transition in Arabidopsis and is recognized as a novel autonomous pathway component [53]. However, transgenic plants overexpressing AtGRP7 and wildtypes using the ATH1 GeneChip did not show significant changes in $F C A$ or $F Y$ under a long-day photoperiod. FLC level was lowered in AtGRP7OX plants. This indicated that RNP may play a multifunctional role in different phase transitions in planta.

Many types of RNA-binding proteins (RBPs) play diverse roles in regulating RNA metabolism in a variety of cellular processes [54]. While analyzing the cellular localization of two rice OsRZ2-GFP and OsRZ3-GFP fusion proteins using a confocal microscope, strong GFP signals were observed in the nuclei of roots of OsRZ2and OsRZ3-expressing Arabidopsis plants [55]. Moreover, the growth of roots in OsRZ2-overexpressing grp7 plants was higher than wildtype and grp7 plants, demonstrating that RNPs influence root growth in Arabidopsis plants $[56,57]$. The restoration of rooting competence is an obvious correlative characteristic of Sequoia rejuvenation (Figure 1). In Figure 6SsRNP displayed greater homology in the amino acid sequence with AtGRP7 and demonstrated a potential role RNPs in root growth.

Although the expression level of SsRNP in the steps of repeated grafting in the present study suggested no correlation between rejuvenation and protein/transcript abundance of the SsRNP gene in Sequoia shoot cultures initiated in 1976 or 1994, SsRNP still appeared to play a possible role in the restoration of rooting competence during rejuvenation. A previous study showed that OEE2 can be phosphorylated by a RNP-mediated wallassociated kinase [58]. Additionally, a phosphopeptide of OEE2 was identified in this study (Table 1). Whether the phosphorylation of OEE2 is involved in the rejuvenation of Sequoia and whether RNP and OEE2 are coordinated during rejuvenation require further studies.

Glycine-rich protein (GRP) has been shown to be abundant in the xylem cell wall and participate in wood formation [59-63]. GRPS were also shown to play an important role in cold adaptation in a biosphere $[57,60,62,64]$. Therefore, a higher expression level of GRP was present in the later wood, consisting of cells with smaller lumens and thicker cell walls during the chill season $[59,60]$. Glycine-rich RNA binding proteins (RNP) belong to the Class IV GRPs and are involved in stress adaptation $[53,54,65,66]$. The expression level of SsRNP in Sequoia shoot cultures initiated in 1976 displayed a similar expression level during the adult, juvenile, and rejuvenile stages but exhibited slightly increased levels during the juvenile and rejuvenile stages compared with the adult stage in shoots initiated in 1994 (Figure 8). 


\section{Identification of thaumatin-like protein}

Thaumatin-like proteins (TLP) are a class of superfamily proteins participating in several biological processing [67]. The expression level of SsTLP was higher in the adult stage and decreased with successive grafts. The expression level showed an opposite pattern with $S S O E E 2$. TLP is well known to belong to pathogenesisrelated (PR) protein family 5 (PR5) [68]. Most TLPs have strong antifungal activity [69-71], but some TLPs have little or no antifungal activity [72,73]. SsTLP displayed high homology with two TLPs-Cryj 3.1 and Cryj 3.2 isolated from Cryptomeria japonica [74]. Several TLPs isolated from Cryptomeria japonica have different expression patterns in plant tissue, with a higher expression level of Cryj 3.1 in the reproductive organ. Furthermore, gSN-TLP isolated from elderberry trees (Sambucus nigra L.) also displayed higher expression levels in older leaves compared with younger leaves [75]. These studies indicate that TLPs could be an adult trait and worthy of future investigations of their function in rejuvenation.

\section{Conclusions}

In the present study, three proteins differentially accumulated during different rejuvenation stages in Sequoia sempervirens. These included OEE2, TLP and RNP. The protein abundance and transcript abundance of a phosphoprotein SsOEE2 were consistently lower in Sequoia shoots during the adult stage but increased with repeated grafting. This correlation between rejuvenation and protein and transcript abundance of the genes suggested that SSOEE2 is associated with rejuvenation, and may be involved in Sequoia sempervirens rejuvenation.

\section{Materials and methods}

\section{Tissue culture}

Continuously cultured Sequioa sempervirens (D. Don) Endl. shoots from freshly germinated seedlings served as the juvenile rootstocks, and those from mature trees provided the adult shoot meristems. The continuous cultures were initiated from terminals of juvenile and adult shoots and from scion-growth remnants following regrafting of shoot tips. One centimeter long terminals were subcultured at 6 week intervals in nutrient media containing Murashige and Skoog salts [76], 3\% sucrose, $0.2 \%$ gelrite, $555 \mu \mathrm{M}$ myo-inositol, $3 \mu \mathrm{M}$ thiamine $\mathrm{HCl}, 2.4 \mu \mathrm{M}$ pyridoxine $\mathrm{HCl}, 4.1 \mu \mathrm{M}$ nicotinic acid, and $26.6 \mu \mathrm{M}$ glycine. Grafting was performed by inserting the obliquely cut base of a $1.5 \mathrm{~cm}$ long shoot terminal into a longitudinal incision made in a rooted $1 \mathrm{~cm}$ tall juvenile stem segment. Regrafting was performed at 8 week intervals. Shoot cultures and grafted plants were maintained at $27^{\circ} \mathrm{C}$ with $16 \mathrm{~h}$ daily exposure to $22.5 \mu \mathrm{mol} \mathrm{m} \mathrm{m}^{-2}$ cool-white fluorescent light.

\section{Plant materials}

Sequoia shoots at different developmental stages or phases were cultured as previously described [16]. The adult shoot stocks were established by culturing shoot tips excised in 1976 and 1994. Cultures of juvenile shoot cuttings maintained as shoot stocks were established using fresh in vitro germinated seeding. Rejuvenated shoots were obtained by grafting the shoot tips five times from the two adult Sequoia shoots by grafting the adult shoot tips onto juvenile rootstocks. After grafting, shoots were severed and maintained in stocks by subculturing $2-3 \mathrm{~cm}$ terminal sections every 2 months in MSbased medium [76].

\section{Protein extraction}

This method was modified from a previous study [77]. Two grams of the plant sample were ground with a mortar and pestle in liquid nitrogen. 0.15-0.2 $\mathrm{g}$ of the sample was transferred to 10 Eppendorff centrifuge tubes. Each tube was washed with a 10 -fold volume of cold $10 \%$ trichloroacetic acid/acetone containing, successively, 0.07\% 2-mercaptoethanol, cold $80 \%$ methanol containing $0.1 \mathrm{M}$ ammonium acetate and $0.07 \% 2$ mercaptoethanol, and cold $80 \%$ acetone containing 0.07\% 2-mercaptoethanol and cold 100\% acetone. After each wash, all tubes were centrifuged at $16,000 \times g$ at $4^{\circ} \mathrm{C}$ for $5 \mathrm{~min}$, and the supernatant was discarded. When all washes were finished, the pellets were air dried at room temperature for at least $10 \mathrm{~min}$, and $0.8 \mathrm{~mL} 0.1 \mathrm{~g}^{-1}$ of a starting sample of $1: 1$ phenol/ sodium dodecyl sulfate (SDS) buffer was added, mixed thoroughly, incubated for $10 \mathrm{~min}$, and centrifuged at $16,000 \times g$ at $4^{\circ} \mathrm{C}$ for $10 \mathrm{~min}$. The phenol phase was pipetted into a $50 \mathrm{ml}$ falcon tube. At least 3-5 volumes of cold methanol containing $0.1 \mathrm{M}$ ammonium acetate and $0.07 \% 2$-mercaptoethanol were added. The tube was stored at $-20^{\circ} \mathrm{C}$ overnight. The falcon tube was centrifuged at $3,000 \times g$ at $4{ }^{\circ} \mathrm{C}$ for $10 \mathrm{~min}$ the next day. The precipitates were washed twice with cold methanol containing $0.07 \% 2$-mercaptoethanol and twice with $80 \%$ cold acetone containing $0.07 \% 2$ mercaptoethanol. Following each washing step, the falcon tube was centrifuged at $3,000 \times g$ at $4{ }^{\circ} \mathrm{C}$ for $10 \mathrm{~min}$. Finally, the pellet was resuspended with $16 \mathrm{~mL}$ cold $100 \%$ acetone and aliquoted into eight $2.0 \mathrm{~mL}$ Eppendorff centrifuge tubes. These tubes were then centrifuged at $16,000 \times g$ at $4^{\circ} \mathrm{C}$ for $5 \mathrm{~min}$, and the supernatant was discarded. The pellet was air dried at room temperature for at least $10 \mathrm{~min}$ and dissolved in $200 \mu \mathrm{L}$ rehydration buffer (6 M urea, $2 \mathrm{M}$ thiourea, $0.5 \%$ triton $\mathrm{X}-100$, and a trace of bromophenol blue), and the tubes were stored at $-80^{\circ} \mathrm{C}$ overnight. 


\section{Isoelectric focusing and two-dimensional gel electrophoresis}

A $1.5 \mathrm{~mL}$ Eppendorff centrifuge tube was prepared. An appropriate volume of protein sample containing $800 \mu \mathrm{g}$ of protein was mixed with $3.8 \mathrm{mg}$ dithiothreitol (DTT) and $0.5 \mu \mathrm{L}$ ampholyte in the tube. Rehydration buffer was added to achieve a final volume of $500 \mu \mathrm{L}$. The protein sample was loaded onto the focusing tray and covered with a $17 \mathrm{~cm}, \mathrm{pH} 3-10$, immobilized $\mathrm{pH}$ gradient (IPG) strip (linear). Active rehydration was performed on a Bio-Rad Protean IEF cell under 50 voltage for $14 \mathrm{~h}$. Isoelectric focusing was performed on the same machine using the following program: $250 \mathrm{~V}$, linear ramp for $20 \mathrm{~min} ; 10,000 \mathrm{~V}$, linear ramp for $3 \mathrm{~h}$; and $10,000 \mathrm{~V}$ for a total of $60,000 \mathrm{Vh}$. Strips were stored at $-80^{\circ} \mathrm{C}$ overnight. The strips were thawed, and equilibration began with SDS equilibration buffer (50 mM Tris- $\mathrm{HCl}, \mathrm{pH} 8.8$, $6 \mathrm{M}$ urea, $30 \%$ glycerol, $2 \%$ SDS, and a trace of bromophenol blue) the following day. The strips were kept in equilibration buffer 1 (SDS equilibration buffer containing 1\% DTT) and shaken for 15-20 min. The strips were moved into equilibration buffer 2 (SDS equilibration buffer containing 2.5\% iodoacetamide) for 15-20 min. The strips were then layered on $12 \%$ acrylamide gel and embedded in the place of agarose. Electrophoresis was performed on a Bio-Rad Protean II xi Cell (step 1: $32 \mathrm{~mA}$ for $30 \mathrm{~min}$; step 2: $90 \mathrm{~mA}$ for $270 \mathrm{~min}$ ) and stopped when the indicated blue line reached the bottom of the gel. Gels were then washed with distilled and deionized water once for $5 \mathrm{~min}$ and fixed with fixative buffer (50\% methanol and 7\% acetic acid) overnight. Gels were washed three times with $\mathrm{ddH}_{2} \mathrm{O}(10 \mathrm{~min}$ each), and then the stained gels were stained with Sypro Ruby for 4-5 h. Stained gel images were scanned using a GE Typhoon 9400. Gel images were compared using SameSpots (Progenesis, UK) software.

\section{In-gel digestion of proteins}

Two-dimensional gel spots were excised with cut tips individually. Cut gels were soaked in $50 \mathrm{mM}$ dithioerythreitol (DTE)/25 mM ammonium bicarbonate ( $\mathrm{pH} 8.5$ ) at $37^{\circ} \mathrm{C}$ for $1 \mathrm{~h}$ and soaked in $100 \mathrm{mM}$ iodoacetamide/ $25 \mathrm{mM}$ ammonium bicarbonate ( $\mathrm{pH} \mathrm{8.5)}$ at room temperature for $1 \mathrm{~h}$ in the dark. Gel samples were then soaked in $50 \%$ acetonitrile/ $25 \mathrm{mM}$ ammonium bicarbonate buffer ( $\mathrm{pH} 8.5)$ three times (15 min each), followed by centrifugation at $10,000 \times g$ for 1 min each. Gel samples were soaked with $100 \%$ acetonitrile for $5 \mathrm{~min}$. After removing acetonitrile, gel samples were dried in a Speed Vac for approximately $10 \mathrm{~min}$. One hundred nanograms of trypsin and $40 \mu \mathrm{L} 25 \mathrm{mM}$ ammonium bicarbonate were added to each gel sample and incubated at $37^{\circ} \mathrm{C}$ for at least $16 \mathrm{~h}$. Fifty $\mu \mathrm{L}$ of $50 \%$ acetonitrile/5\% trifluoroacetic acid (TFA) was added to each gel sample and sonicated for $10 \mathrm{~min}$. The above step was repeated, combined peptide solutions was dried in a Speed Vac for $90 \mathrm{~min}$. Dried peptide pellets were prepared for liquid chromatography-MS/MS (LC-MS/MS) using Mass Solutions Technology.

\section{Mass spectrometry analyses and protein identification}

Peptide samples were analyzed by LC/MS/MS using Q-TOF (Waters, UK) or LTQ Velos (Thermo, US). Peak list files were generated from RAW files. Protein identification was performed using in-house Mascot software (Matrixscience, US) [78]. The mass peak list data were searched against the National Center for Biotechnology Information database using green plant taxonomy. For the Q-TOF dataset, mass tolerance was set to $0.6 \mathrm{D}$. For the LTQ dataset, mass tolerance was set to $1 \mathrm{D}$. The missed cleavage site was set to 1 . To validate the identified peptides or proteins, Scaffold software (Proteome Software, US) was used to provide confidence interval percentages for the identification of peptides and proteins.

\section{Statistical analyses of gel spot intensity}

Statistical analyses were performed using SPSS 16.0 software (SPSS, Chicago, IL, USA) to compare the protein abundance of the gel spots. Significant effects $(p<0.05)$ in the one-way ANOVA were followed by Duncan's multiple range test.

\section{RNA extraction}

One gram of sample was ground in the mortar treated with liquid nitrogen. The sample powder was mixed with $10 \mathrm{~mL}$ extraction buffer (10 g polyvinylpyrrolidone, $10 \mathrm{~g}$ hexadecyltrimethylammonium bromide, $4.653 \mathrm{~g}$ ethylenediaminetetraacetic acid [EDTA], 58.44 g sodium chloride, 0.25 g spermidine, and fresh $200 \mu \mathrm{l} \beta$-mercaptoethanol). After heating the slurry at $65^{\circ} \mathrm{C}$ in a water bath for $10 \mathrm{~min}$, delaminating was performed by $13,000 \mathrm{rpm}$ centrifugation at $25^{\circ} \mathrm{C}$ for $15 \mathrm{~min}$. The supernatant was mixed well with chloroform and isoamylalcohol twice, and the total RNA was collected after precipitation with a 1/4-fold volume of $10 \mathrm{M}$ lithium chloride at $4^{\circ} \mathrm{C}$ overnight.

\section{Rapid amplification of CDNA end and cloning of gene of interest}

Total RNA was dephosphorylated by alkaline phosphatase and then decapped by acid pyrophosphatase. The completed mRNA was ligated using a GeneRacer RNA oligo (Invitrogen, Carlsbad, California, USA), and cDNA was formed by reverse transcription. The cDNA was used as the template for cloning the genes of interest using the following steps: denaturation at $94^{\circ} \mathrm{C}$ for $2 \mathrm{~min}$, followed by 20 cycles of amplification (i.e., $94^{\circ} \mathrm{C}$ for $30 \mathrm{~s}$ for denaturation, $47-66^{\circ} \mathrm{C}$ for $30 \mathrm{~s}$ for annealing, depending on the genes, $72^{\circ} \mathrm{C}$ for $30 \mathrm{~s}$ for elongation) 
and extension at $72^{\circ} \mathrm{C}$ for $10 \mathrm{~min}$. For cloning OEE2, the primers were OEE25primer (5-CGCGCATAACACTCGGAGGA-3) and OEE25primer (5-CGAAA CCCTAA AATGTGCTT-3). For cloning TLP, the primer are TLP5-primer:5-CGTGGACTGAAGGAGTAGAA-3 and TLP-3primer:5-AACAACTAACGATA GCATATTTTATTTTGTAA-3.For cloning RNP, the primers were RNP5primer (5-GGAGTAGAAAGACTGGAGCA-3) and RNP3primer (5-CTCAAATCATTCATTATCCA-3). The amplified DNA fragments of each candidate gene were cloned in pGEM-Teasy vector (Promega, Madison, WI, USA), and the sequences were identified. The confirmed gene sequences were deposited in GenBank with the accession number assigned.

\section{Northern blotting}

The cDNA fragments were randomly labeled with $\mathrm{P}^{32}$ dCTP (Rediprime II Kit, Amersham) as the probe to hybridize the RNA-blotted membranes, and the membranes were washed following the standard protocol. The membrane was exposed to a Xuorescent plate for $12 \mathrm{~h}$ (Typhoon 9400, Amersham). Band intensities were normalized with respect to the amount of loaded mRNA.

\section{Additional material}

Additional file 1: Validation of protein identification using Scaffold software. This file provided the confidence evidence of the identification of each protein using Scaffold software.

Additional file 2: Identification of other proteins from twodimensional gel. Proteins not consistently identified among different Sequoia gel spots were listed in this table.

Additional file 3: Protein abundance of spots on the $2 \mathrm{D}$ gel. RAW data of protein abundance of spot 1, 2, and 3 in each Sequoia samples.

Additional file 4: ANOVA and Duncan's multiple range test for the protein abundance of spots on the $2 \mathrm{D}$ gel. RAW data of ANOVA and Duncan's MRT analyses carried out using SPSS software (Ver. 16.0). A: OEE2; B:RNP; C:Thaumatin-like protein. 1:Adult76; 2:Adult94; 3:Juvenile; 4: Rejuvenated76; 5:Rejuvenated94.

\section{Abbreviations}

DCMU: 3-(3,4-dichlorophenyl)-1,1-dimethylurea; DTE: dithioerythreitol; DTT: dithiothreitol; EDTA: ethylenediaminetetraacetic acid; GRP: glycine-rich protein; IPG: immobilized pH gradients; LC-MS/MS: liquid chromatographymass spectrometry/mass spectrometry; OEE2: oxygen-evolving enhancer protein 2; Q-TOF: Quatropde-Time of Flight; RBP: RNA-binding protein; RNP: glycine-rich RNA-binding protein; SDS: sodium dodecyl sulfate; TFA: trifluoroacetic acid; TLP: thaumatin-like protein.
\end{abstract}

\section{Acknowledgements}

This investigation was supported by Academia Sinica Project IPMB-2372 and National Taiwan University and National Science Council (grant \#97-2311-B002-005-MY3). The authors thank Prof. Toshio Murashige for critically reading the manuscript and advice on the subject. We appreciate the help from Technology Commons, College of Life Science, National Taiwan University. The English was proofreading by BioMed Proofreading, LLC.

\section{Author details}

'Institute of Plant Biology, National Taiwan University, Taipei 106, Taiwan. Institute of Plant and Microbial Biology, Academia Sinica, Taipei, Taiwan. ${ }^{3}$ Institute of Genomics and Bioinformatics, National Chung Hsing University, Taichung, Taiwan.

\section{Authors' contributions}

IFC, TJH, and YWH performed 2DE and protein identification. IFC participated in the overall experimental design and quality control of MS data. TJH and YWH performed the protein isolation, two-dimensional gel electrophoresis, MS analyses, and protein identification. CHS and PJC performed the RACE of the genes of interest and Northern blotting. BLH, CIK, and LCH performed the sample preparation. KWY coordinated the preparation of the final manuscript. All authors read and approved the final manuscript.

\section{Competing interests}

The authors declare that they have no competing interests.

Received: 7 August 2010 Accepted: 10 December 2010 Published: 10 December 2010

\section{References}

1. Poethig RS: Phase change and the regulation of shoot morphogenesis in plants. Science 1990, 250:923-930.

2. Rogler CE, Hackett WP: Phase change in Hedera helix: induction of the mature to juvenile phase change by gibberellin A3. Physiol Plant 1975, 34:141-147.

3. Bouriquet $R$, Tsogas M, Blaselle A: Essais de rajeunissement de l'Epicea par les cytokinins. Ann AFOCEL 1985, 1984:173-185.

4. Franclet A, Boulay M, Bekkaoui F, Fouret $Y, M B$. V, Walker N: Rejuvenation. In Cell and Tissue Culture in Forestry. Volume 2. Edited by: Bonga JM, Durzan DJ. Martinus Nijhoff Publishers; 1987:232-248.

5. Brand MH, Lineberger RD: In vitro rejuvenation of Betula (Betulaceae): morphological evaluation. Am J Bot 1992, 79:618-625.

6. Fouret $Y$, Arnaud $Y$, Larrieu C: Rajeunissement in vitro du Sequoia sempervirens. Ann AFOCEL 1985, 1984:111-137.

7. Lyrene PM: Juvenility and production of fast-rooting cuttings from blueberry shoot cultures. J Amer Soc Hort Sci 1981, 106:396-398.

8. Doorenbos J: "Rejuvenation" of Hedera helix in graft combinations. Ned Akad Wetensch Amsterdam, Proc 1954, 57:99-102.

9. Muzik TJ, Cruzado HJ: Transmission of juvenile rooting ability from seedlings to adults of Hevea-Brasiliensis. Nature 1958, 181:1288-1288.

10. Ewald $D$, Kretzschmar $U$ : The influence of micrografting in vitro on tissue culture behavior and vegetative propagation of old European larch trees. Plant Cell Tiss Organ Cult 1996, 44:249-252.

11. Huang LC, Hsiao CK, Lee SH, Huang BL, Murashige T: Restoration of vigor and rooting competence in stem tissues of mature Citrus by repeated grafting of their shoot apices onto freshly germinated seedlings in vitro. In Vitro Cell Dev Biol-Plant 1992, 28:30-32.

12. Kuo JL, Huang HJ, Cheng CM, Chen LJ, Huang BL, Huang LC, Kuo TT: Rejuvenation in vitro: modulation of protein phosphrylation in Sequoia sempervirens. J Plant Physiol 1995, 146:333-336.

13. Monteuuis $\mathrm{O}$ : Microgreffage de points vegetatifs de Sequoiadendron giganteum Bucholz. Seculaires sur de jeunes emis cultives in vitro. $C R$ Acad Sci Paris 1986, 302:223-225.

14. Pliego-Alfaro F, Murashige T: Possible rejuvenation of adult avocado by graftage onto juvenile rootstocks in vitro. HortScience 1987, 22:1321-1324.

15. Revilla MA, Pacheco J, Casares A, Rodriguez R: In vitro reinvigoration of mature olive trees (Olea europaea L.) through micrografting. In Vitro Cell Dev Biol Plant 1996, 32:257-261.

16. Huang LC, Lius S, Huang BL, Murashige T, Mahdi EF, Van Gundy R: Rejuvenation of Sequoia sempervirens by Repeated Grafting of Shoot Tips onto Juvenile Rootstocks in Vitro: Model for Phase Reversal of Trees. Plant Physiol 1992, 98:166-173.

17. Huang HJ, Chen Y, Kuo JL, Kuo TT, Tzeng CC, Huang BL, Chen CM, LC H: Rejuvenation of Sequoia sempervirens in vitro changes in isoesterase and isoperoxidase. Plant Cell Physiol 1996, 37:77-80.

18. Huang LC, Pu SY, Murashige T, Fu SF, Kuo TT, Huang DD, Huang HJ: Phaseand Age-Related Differences in Protein Tyrosine Phosphorylation in 
Sequoia sempervirens. Biologia Plantarum 2003, 47:601-603.

19. Huang $\mathrm{LC}, \mathrm{Kuo} \mathrm{Cl}$, Wang $\mathrm{CH}$, Murashige T, Huang TC: Ethylene evolution by juvenile and adult developmental phase of Sequoia sempervirens shoots cultured in vitro. Bot Bull Acad Sinica 2000, 41:263-266.

20. Huang LC, Weng JH, Wang CH, Kuo Cl, Shieh YJ: Photosynthetic potentials of in vitro-grown juvenile, adult and rejuvenated Sequoia sempervirens (D. Don) Endl. shoots. Bot Bull Acad Sinica 2003, 44:31-35.

21. Bon MC, Monteuuis O: Rejuvenation of a 100-year-old Sequoiadendron giganteum through in vitro meristem culture. II. Biochemical arguments. Physiologia Plantarum 1991, 81:116-120.

22. Hand P, Besford RT, Richardson CM, Peppitt SD: Antibodies to phase related proteins in juvenile and mature Prunus avium. Plant Growth Regulation 1996, 20:25-29.

23. Gil B, Pastoriza E, Ballester A, Sánchez C: Isolation and characterization of a cDNA from Quercus robur differentially expressed in juvenile-like and mature shoots. Tree Physiology 2003, 23:633-640.

24. Hochholdinger F, Sauer M, Dembinsky D, Hoecker N, Muthreich N, Saleem M LY: Proteomic dissection of plant development. Proteomics 2006, 6:4076-4083

25. Thomas H: Ageing in plants. Mech Ageing Dev 2002, 123:747-753.

26. Munne-Bosch S: Do perennials really senesce? Trends Plant Sci 2008, 13:216-220.

27. Bond BJ: Age-related changes in photosynthesis of woody plants. Trends in Plant Science 2000, 5:349-353.

28. Greenwood MS: Juvenility and maturation in conifers: current concepts. Tree Physiology 1995, 15:433-438.

29. Nyitrai P, Kovacs E, Kiraly I, Ovari M, Keresztes A: On the mechanism of rejuvenation of ageing detached bean leaves by low-concentration stressors. Plant Biol (Stuttg) 2009, 11:236-242.

30. Irish EE, McMurray D: Rejuvenation by shoot apex culture recapitulates the developmental increase of methylation at the maize gene PIBlotched. Plant Mol Biol 2006, 60:747-758.

31. Day ME, Greenwood MS, Diaz-Sala C: Age- and size-related trends in woody plant shoot development: regulatory pathways and evidence for genetic control. Tree Physiol 2002, 22:507-513.

32. Washburn CF, Thomas JF: Reversion of flowering in Glycine Max (Fabaceae). Am J Bot 2000, 87:1425-1438.

33. Tooke F, Ordidge $M$, Chiurugwi T, Battey N: Mechanisms and function of flower and inflorescence reversion. J Exp Bot 2005, 56:2587-2599.

34. Fisher JB: Induction of Juvenile Leaf Form in a Palm (Caryota mitis) by Gibberellin. Bulletin of the Torrey Botanical Club 1976, 103:153-157.

35. Greenwood MS: Rejuvenation of forest trees. Plant Growth Regulation 1987, 6:1-12

36. Mohamed F, Swartz HJ, Buta JG: The role of abscisic acid and plant growth regulators in tissue culture-induced rejuvenation of strawberry ex vitro. Plant Cell, Tissue and Organ Culture 1991, 25:75-84

37. Pieringer AP, Hanks RW: Physiology of juvenility in citrus. Annu Rpt Fla Agr Expt Sta 1964-1965 1965, , :: 228-229.

38. Franclet A: Rajeunissement des arbres adultes en vue de leur propagation vegetative. Etudes et Recherches 1979, 12:3-18.

39. Stoutemyer VT, Britt OK: Effect of Temperature and Grafting on Vegetative Growth Phases of Algerian Ivy. Nature 1961, 189:854-855.

40. Lewin IJ, Montaldi ER, Caso OH: Reversibilidad de la forma adulta de la hoja en plantas viejas de Passiflora caerulea L. Rev Investigaciones Agrícolas B Aires 1963, 17:407-411.

41. Franclet $A$ : Rajeunissement et propagation vegetative des ligneux. Ann AFOCEL 1981, , :: 12-41

42. Ghanotakis DF, Yocum CF: Photosystem II and the Oxygen-Evolving Complex. Annual Review of Plant Physiology and Plant Molecular Biology 1990, 41:255-276.

43. Kasten B, Buck F, Nuske J, Reski R: Cytokinin affects nuclear- and plastome-encoded energy-converting plastid enzymes. Planta 1997, 201:261-272.

44. Blodner C, Majcherczyk A, Kues U, Polle A: Early drought-induced changes to the needle proteome of Norway spruce. Tree Physiol 2007, 27:1423-1431.

45. Gendrel AV, Lippman Z, Martienssen R, Colot V: Profiling histone modification patterns in plants using genomic tiling microarrays. Nat Methods 2005, 2:213-218.

46. Abbasi FM, Komatsu S: A proteomic approach to analyze salt-responsive proteins in rice leaf sheath. Proteomics 2004, 4:2072-2081.
47. Vargas WA, Mandawe JC, Kenerley CM: Plant-derived sucrose is a key element in the symbiotic association between Trichoderma virens and maize plants. Plant Physiol 2009, 151:792-808

48. Ido K, Ifuku K, Yamamoto Y, Ishihara S, Murakami A, Takabe K, Miyake C, Sato F: Knockdown of the PsbP protein does not prevent assembly of the dimeric PSII core complex but impairs accumulation of photosystem II supercomplexes in tobacco. Biochimica Et Biophysica Acta-Bioenergetics 2009, 1787:873-881.

49. Ifuku K, Yamamoto Y, Ono T, Ishihara S, Sato F: PsbP protein, but not PsbQ protein, is essential for the regulation and stabilization of photosystem II in higher plants. Plant Physiology 2005, 139:1175-1184.

50. Greenwood MS, Hopper CA, Hutchison KW: Maturation in larch: I. Effect of age on shoot growth, foliar characteristics, and DNA methylation. Plant Physiol 1989, 90:406-412.

51. Woo HH, Hackett WP, Das A: Differential Expression of a Chlorophyll a/B Binding-Protein Gene and a Proline-Rich Protein Gene in Juvenile and Mature Phase English Ivy (Hedera-Helix). Physiologia Plantarum 1994, 92:69-78.

52. Sachetto-Martins G, Franco LO, de Oliveira DE: Plant glycine-rich proteins: a family or just proteins with a common motif? Biochimica Et Biophysica Acta-Gene Structure and Expression 2000, 1492:1-14.

53. Streitner C, Danisman S, Wehrle F, Schoning JC, Alfano JR, Staiger D: The small glycine-rich RNA binding protein AtGRP7 promotes floral transition in Arabidopsis thaliana. Plant J 2008, 56:239-250.

54. Kim JY, Park SJ, Jang B, Jung CH, Ahn SJ, Goh CH, Cho K, Han O, Kang H: Functional characterization of a glycine-rich RNA-binding protein 2 in Arabidopsis thaliana under abiotic stress conditions. Plant J 2007, 50:439-451.

55. Kim JY, Kim WY, Kwak KJ, Oh SH, Han YS, Kang H: Zinc finger-containing glycine-rich RNA-binding protein in Oryza sativa has an RNA chaperone activity under cold stress conditions. Plant Cell Environ 2010, 33:759-768.

56. Kim JS, Jung HJ, Lee HJ, Kim KA, Goh CH, Woo Y, Oh SH, Han YS, Kang H: Glycine-rich RNA-binding protein 7 affects abiotic stress responses by regulating stomata opening and closing in Arabidopsis thaliana. Plant $J$ 2008, 55:455-466.

57. Kim JY, Kim WY, Kwak KJ, Oh SH, Han YS, Kang H: Glycine-rich RNAbinding proteins are functionally conserved in Arabidopsis thaliana and Oryza sativa during cold adaptation process. J Exp Bot 2010, 61:2317-2325.

58. Yang EJ, Oh YA, Lee ES, Park AR, Cho SK, Yoo YJ, Park OK: Oxygen-evolving enhancer protein 2 is phosphorylated by glycine-rich protein 3/wallassociated kinase 1 in Arabidopsis. Biochem Biophys Res Commun 2003 305:862-868

59. Lorenz WW, Dean JF: SAGE profiling and demonstration of differential gene expression along the axial developmental gradient of lignifying xylem in loblolly pine (Pinus taeda). Tree Physiol 2002, 22:301-310.

60. Bocca SN, Magioli C, Mangeon A, Junqueira RM, Cardeal V, Margis R, Sachetto-Martins G: Survey of glycine-rich proteins (GRPs) in the Eucalyptus expressed sequence tag database (ForEST). Genetics and Molecular Biology 2005, 28:608-624.

61. Paiva JAP, Garnier-Géré PH, Rodrigues JC, Alves A, Santos S, Graça J, Le Provost G, Chaumeil P, Da Silva-Perez D, Bosc A, et al: Plasticity of maritime pine (Pinus pinaster) wood-forming tissues during a growing season. New Phytologist 2008, 179:1180-1194.

62. Le Provost G, Paiva J, Pot D, Brach J, Plomion C: Seasonal variation in transcript accumulation in wood-forming tissues of maritime pine (Pinus pinaster Ait.) with emphasis on a cell wall glycine-rich protein. Planta 2003, 217:820-830

63. Kumar M, Saranpää P, Barnett J, Wilkinson M: Juvenile-mature wood transition in pine: correlation between wood properties and candidate gene expression profiles. Euphytica 2009, 166:341-355

64. Fang W, St Leger RJ: RNA binding proteins mediate the ability of a fungus to adapt to the cold. Environ Microbiol 2010, 12:810-820.

65. Lee MO, Kim KP, Kim BG, Hahn JS, Hong CB: Flooding stress-induced glycine-rich RNA-binding protein from Nicotiana tabacum. Mol Cells 2009, 27:47-54.

66. Schmidt F, Marnef A, Cheung MK, Wilson I, Hancock J, Staiger D, Ladomery M: A proteomic analysis of oligo(dT)-bound mRNP containing oxidative stress-induced Arabidopsis thaliana RNA-binding proteins ATGRP7 and ATGRP8. Mol Biol Rep 2010, 37:839-845. 
67. Liu JJ, Sturrock R, Ekramoddoullah AKM: The superfamily of thaumatin-like proteins: its origin, evolution, and expression towards biological function. Plant Cell Reports 2010, 29:419-436.

68. van Loon LC, Rep M, Pieterse CM: Significance of inducible defenserelated proteins in infected plants. Annu Rev Phytopathol 2006, 44:135-162.

69. Garcia-Casado C, Collada C, Allona I, Soto A, Casado R, Rodriguez-Cerezo E, Gomez L, Aragoncillo C: Characterization of an apoplastic basic thaumatin-like protein from recalcitrant chestnut seeds. Physiologia Plantarum 2000, 110:172-180.

70. Chu KT, Ng TB: Isolation of a large thaumatin-like antifungal protein from seeds of the Kweilin chestnut Castanopsis chinensis. Biochem Biophys Res Commun 2003, 301:364-370.

71. Campos MD, Silva MS, Magalhaes CP, Ribeiro SG, Sarto RPD, Vieira EA, de Sa MFG: Expression in Escherichia coli, purification, refolding and antifungal activity of an osmotin from Solanum nigrum. Microbial Cell Factories 2008, 7:7.

72. Barre A, Peumans WJ, Menu-Bouaouiche L, Van Damme EJM, May GD, Herrera AF, Van Leuven F, Rouge P: Purification and structural analysis of an abundant thaumatin-like protein from ripe banana fruit. Planta 2000, 211:791-799.

73. Menu-Bouaouiche L, Vriet C, Peumans WJ, Barre A, Van Damme EJM, Rouge P: A molecular basis for the endo-beta 1,3-glucanase activity of the thaumatin-like proteins from edible fruits. Biochimie 2003, 85:123-131.

74. Futamura N, Tani N, Tsumura Y, Nakajima N, Sakaguchi M, Shinohara K: Characterization of genes for novel thaumatin-like proteins in Cryptomeria japonica. Tree Physiology 2006, 26:51-62.

75. Van Damme EJ, Charels D, Menu-Bouaouiche L, Proost P, Barre A, Rouge P, Peumans WJ: Biochemical, molecular and structural analysis of multiple thaumatin-like proteins from the elderberry tree (Sambucus nigra L.). Planta 2002, 214:853-862.

76. Murashige T, Skoog F: A revised medium for rapid growth and bio-assays with tobacco culture. Physiol Plant 1962, 15:473-497.

77. Wang W, Vignani R, Scali M, Cresti M: A universal and rapid protocol for protein extraction from recalcitrant plant tissues for proteomic analysis. Electrophoresis 2006, 27:2782-2786.

78. Perkins DN, Pappin DJ, Creasy DM, Cottrell JS: Probability-based protein identification by searching sequence databases using mass spectrometry data. Electrophoresis 1999, 20:3551-3567.

doi:10.1186/1477-5956-8-64

Cite this article as: Chang et al:: Proteomic profiling of proteins associated with the rejuvenation of Sequoia sempervirens (D. Don) Endl. Proteome Science 2010 8:64.

\section{Submit your next manuscript to BioMed Central and take full advantage of:}

- Convenient online submission

- Thorough peer review

- No space constraints or color figure charges

- Immediate publication on acceptance

- Inclusion in PubMed, CAS, Scopus and Google Scholar

- Research which is freely available for redistribution

Submit your manuscript at www.biomedcentral.com/submit
Biomed Central 